\title{
Assessing the environmental profit and loss of the textile industry: A case study in China
}

DOI: 10.35530/IT.072.01.1787

\section{ABSTRACT - REZUMAT \\ Assessing the environmental profit and loss of the textile industry: A case study in China}

The textile industry contributes a lot to China's economy in history and present. However, it also causes serious impacts on the environment. Environmental prices methodology was proposed to convert various environmental impacts into corresponding social marginal value and it can be applied for the evaluation of the environmental loads. This study applied environmental prices methodology to calculate the social marginal value of the caused environmental impacts in China's textile industry during the period from 2001 to 2015. The results showed that the minimum value of caused environmental impacts was $€ 9.556$ billion and the maximum value was $€ 16.599$ billion. Among the three sub-industries of China's textile industry, Manufacture of Textile had the highest value, followed by Manufacture of Chemical Fibers, and Manufacture of Textile, Wearing Apparel and Accessories. The value of greenhouse effect caused by $\mathrm{CO}_{2}$ emission was the largest. The value of ammonia nitrogen in wastewater was the largest and followed by the values of COD, As, cyanide, $\mathrm{Hg}, \mathrm{Pb}$ and $\mathrm{Cd}$. An in-depth analysis of the results indicated that the social marginal value of the textile industry closely related to the scale of the industry, the international market and government policies.

Keywords: environmental price, social marginal value, environmental load, textile industry, impact pathway model

\section{Evaluarea profitului și pierderii de mediu din industria textilă: un studiu de caz din China}

Industria textilă a contribuit foarte mult la economia Chinei în istorie și în prezent. Cu toate acestea, provoacă și daune grave asupra mediului. S-a propus metodologia calculării prețurilor de mediu pentru a converti diferitele tipuri de impact asupra mediului în valoare socială marginală corespunzătoare și aceasta poate fi aplicată pentru evaluarea impactului asupra mediului. Acest studiu a aplicat metodologia prețurilor de mediu pentru a calcula valoarea socială marginală a impactului asupra mediului cauzat de industria textilă din China în perioada 2001-2015. Rezultatele au arătat că valoarea minimă a impactului asupra mediului a fost de 9.556 miliarde euro, iar valoarea maximă a fost de 16.599 miliarde euro. Dintre cele trei ramuri ale industriei textile din China, fabricarea produselor textile a avut cea mai mare valoare, urmată de fabricarea fibrelor chimice și fabricarea produselor de îmbrăcăminte și accesoriilor. Valoarea efectului de seră cauzat de emisiile de $\mathrm{CO}_{2}$ a fost cea mai mare. Valoarea azotului amoniacal în apele uzate a fost cea mai mare și a fost urmată de valorile $C O D$, As, cianură, $\mathrm{Hg}, \mathrm{Pb}$ și Cd. O analiză aprofundată a rezultatelor a indicat faptul că valoarea socială marginală a industriei textile este strâns legată de amploarea industriei, de piața internațională și de politicile guvernamentale.

Cuvinte-cheie: prețul de mediu, valoarea socială marginală, impactul asupra mediului, industria textilă, modelul evaluării impactului

\section{INTRODUCTION}

China is the largest producer, exporter and consumer of textile and clothing products. The textile industry is a pillar of China's national economy. However, textile industry consumes large quantities of freshwater, energy and chemicals in the production of textile products. More severely is that the textile industry discharges wastewater and emits waste gases that not only cause high economic losses, but also cause serious damage to human health and ecological system [1, 2]. The quantification and assessment of environmental impacts caused in the textile industry has gained more and more attention. Single index methodologies, such as water footprint (WF), carbon footprint (CF) and chemical footprint (ChF) have been proposed and widely applied in environmental impacts quantification and assessment of textile products. For example, Chapagain et al. [3] calculated the green water footprint, blue water footprint and grey water footprint of cotton from 1997 to 2001. Wang et al. [4] analyzed the industrial water footprint of seven kinds of dyed cotton knits. Yan et al. [5] calculated the industrial water footprint of heather grey, bleached cloth, dyed fabric and yarn-dyed fabric. Yao [6] calculated the carbon footprint of cotton fiber and divided its system boundary into four stages. Li et al. [7] discussed the calculation method of C 18.2 tex cotton carded yarn carbon footprint in each stage. There are also sufficient literatures on various fabrics 
and garments of carbon footprint, such as polyester filament fabric [8], gambiered Carbon silk [9] and jean [10]. Qian et al. [11] calculated the chemical footprint of denim fabric during dyeing and finishing, including human toxicity and ecological toxicity. Tian et al. [12] studied the chemical footprint of textiles and proposed the need for uncertainty analysis of characteristic factors and optimization of the USEtox model to improve the accuracy of the results. However, both water footprint, carbon footprint and chemical footprint are single indicators, which only quantify a part of the environmental impact in a specific area.

With the in-depth study and widely application of environmental assessment methodology, the European Commission proposed product environmental footprint (PEF) methodology in 2012 [13]. PEF is a multicriteria measure of the environmental performance, which quantifies the integrated environmental load of products or services by incorporating different types of environmental impact category. He et al. [14] constructed 14 environmental models based on PEF theory and applied them to environmental assessment of agricultural picking robot. Pyay et al. [15] evaluated the environmental footprint of rubber products in Thailand from plantation phase to intermediate rubber products stage. In addition, PEF has also been applied in the environmental evaluation of dairy products [16], photovoltaic modules [17], strawberries [18], olive oil [19] and other products.

All the proposed indicators (e.g., WF, CF, ChF, PEF) evaluate the environmental impacts at the midpoint level and the substantial environmental impact (for human health, ecosystems, resources, etc) cannot be indicated. In order to solve this problem, Goedkoop et al. [20] developed a new characterization model that can transform environmental impact at the midpoint level to the endpoint level. The impact pathway approach used in the externe project [21] also established the relationship between emissions and endpoint environmental impacts. Sander et al. [22] established the environmental prices, which can convert various impacts of endpoint level into corresponding external costs, and finally obtain the economic loss caused by resources consumption and pollutants emissions. This method has been used in the study of average environmental prices in EU28 countries [23]. Other similar methods such as True Price, Trucost, PwC-environmental profit and loss account (EP\&L) were also established and applied. For example, the real price of a T-shirt made of certified cotton produced in India was $€ 22.3$, of which the external cost was $€ 7.3$ [24]. The true price of a pair of jeans was $€ 30$ higher than the traditional market price. The price gap was mainly contributed by environmental external costs and social external costs [25]. In addition to the applications on textile products, True Price also calculated the external costs of cocoa [26], tea [27], banana [28] and other products. Trucost worked with PwC to carry out an EP\&L study, which stated that the total monetary impact of PUMA's direct and supply chain operations was $€ 145$ million in 2010 [29]. Similar studies of EP\&L included
Novo Nordisk [30], American Chemistry Council [31] and The Green Electronics Council [32], etc. These methods converted environmental impacts into external cost, but there were differences in the specific evaluation methods. Environmental prices [22] evaluated 11 kinds of midpoint impacts (i.e., ozone depletion, climate change, particulate matter formation, photochemical oxidant formation, acidification, eutrophication, human toxicity, ecotoxicity, ionizing radiation, noise and land use), while PwC-EP\&L mainly included air pollution, greenhouse gases, land use, solid waste, water consumption and water pollution [33]. Although the impacts of the midpoint level were different, the evaluation of the endpoint level was similar, that mainly included the impact on human health, ecosystem services, buildings and materials, etc. In terms of social impact, True Price considered more detailed categories [34], including gender inequality, public safety risks and breaches of privacy, etc. The method of environmental prices was also considered the impact of wellbeing [22]. The applications of True Price and Trucost were mostly focused on specific products (T-shirt, bananas, cocoa, etc.), while EP\&L research was mainly applied at the enterprise and organizational level. However, there are few reports on environmental impacts assessment of the textile industry based on EP\&L methodology though the textile industry does cause serious environmental impacts.

Therefore, this paper calculated the external cost of environmental damage caused by China's textile industry with the environmental profit and loss methodology. The parts of this paper are organized as follows. Section 2 provides methodology and data. The results are discussed in section 3 . Section 4 is the conclusion of this paper.

\section{METHODOLOGY AND DATA}

\section{Method}

Environmental prices methodology is regarded as a more scientific method to evaluate the social marginal value of preventing emissions [22]. It establishes the impact of emissions on 11 environmental midpoints, including ozone depletion, climate change, human toxicity, etc. It evaluates the endpoint damage caused by each midpoint to human health, ecosystem services, buildings/materials, resource availability and wellbeing, and finally calculates the external cost of these damages. The method consists of three important parts: characterization models, impact pathway models and valuation methods. The overall framework is shown in figure 1.

Characterization model

The characterization model quantifies the physicochemical relationship among emissions, midpoint impacts and endpoint damages. The midpoint characteristic factor (CFm) is obtained by introducing relevant environmental impact pollutants to quantify the relationship between emission and midpoint. The endpoint characteristic factor (CFe) is obtained by analysing the damages caused by the midpoints to 


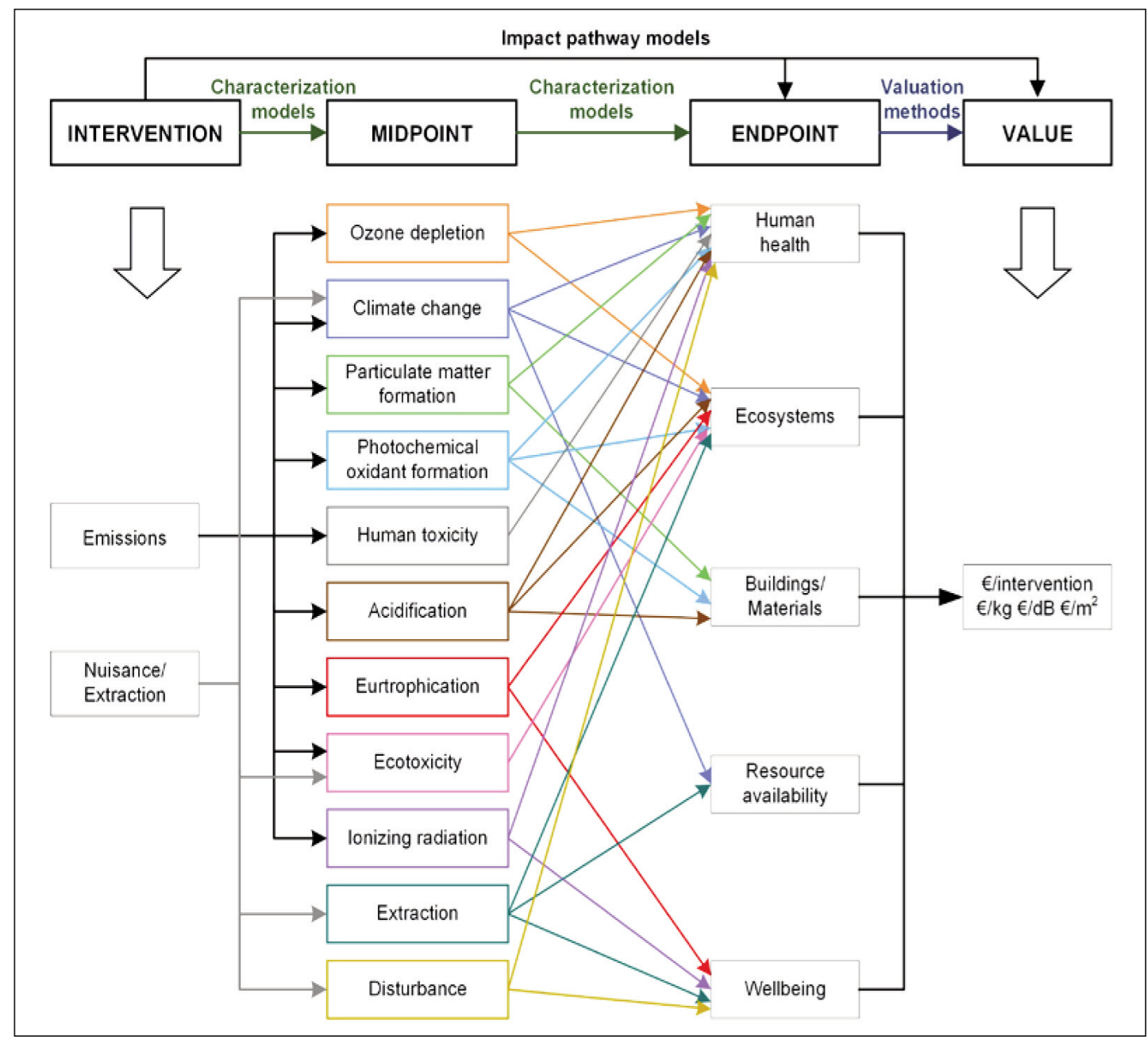

Fig. 1. The framework of environmental prices methodology

different protection areas (human health, ecosystem quality and resource scarcity) [20].

In order to maintain the consistency of midpoint and endpoint impacts, different cultural perspectives (i.e., Individualist, Hierarchist and Egalitarian) are adopted. The CFm and CFe can be calculated as follows:

$$
\begin{gathered}
\mathrm{CFm}_{\mathrm{x}, \mathrm{c}}=\frac{\mathrm{S}_{\mathrm{x}, \mathrm{c}}}{\mathrm{S}_{\mathrm{r}, \mathrm{c}}} \\
\mathrm{CFe}_{\mathrm{x}, \mathrm{c}, \mathrm{a}}=\mathrm{CFm}_{\mathrm{x}, \mathrm{c}} \times \mathrm{F}_{\mathrm{m} \rightarrow \mathrm{e}_{\mathrm{c}, \mathrm{a}}}
\end{gathered}
$$

where $\mathrm{CFm}_{\mathrm{x}, \mathrm{c}}$ is the midpoint characterization factor of substance $x$ for cultural perspective $c$. $S_{x, c}$ is the amount of substance $x$ for cultural perspective $c$. $S_{r, c}$ is the amount of reference substance $r$ for cultural perspective c. $\mathrm{CFe}_{\mathrm{x}, \mathrm{c}, \mathrm{a}}$ is the endpoint characterization factor of substance $\mathrm{x}$ for cultural perspective $\mathrm{C}$ and area of protection $a . F_{m \rightarrow e_{c a}}$ is the conversion factor from midpoint to endpoint for cultural perspective $\mathrm{c}$ and area of protection a.

Impact pathway model

The impact pathway model is a bottom-up method, which can simulate the dispersion and chemical transformation of emission in different environmental media, and convert it into corresponding concentration. The effect on the endpoint is quantified by dose-response function and the impact is assigned to the corresponding monetary value. The specific steps are shown in figure 2 .

The model of Meteorological Synthesizing CentreWest of European Monitoring and Evaluation Programme (EMEP/MSC-West) is adopted in the process of emission concentration conversion, which distributes the changes of concentration and deposition per unit of emission into the EMEP grid cells to establish the relationship between emission and concentration in specific areas. The concentrationresponse function is used to evaluate the endpoint effect in each EMEP grid cell. It can be expressed by mortality, morbidity and potentially disappearing species.

\section{Valuation method}

Valuation method establishes the economic relationship between the impacts of the endpoint and the external costs. The model calculates the external costs of five environmental endpoints: human health, ecosystem, building materials, resources and welfare. The valuations are different in different endpoints. For example, the impact of human health is generally expressed in terms of mortality and morbidity, which are measured in life years. Value of a Life Year (VOLY) assigns the monetary values for 


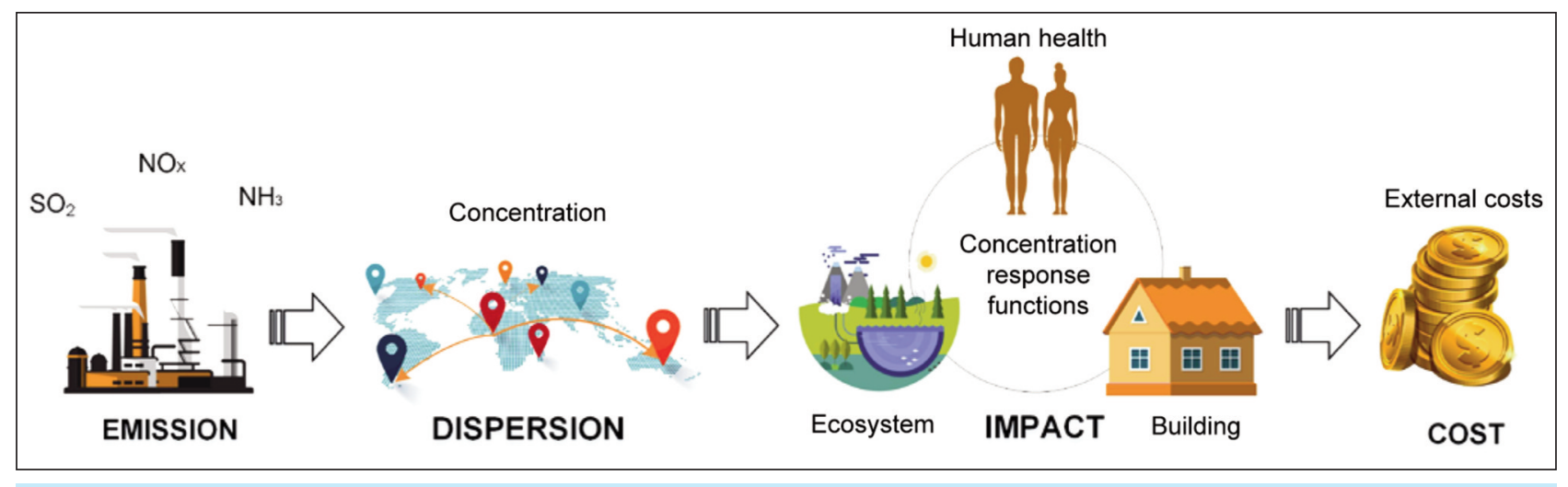

Fig. 2. Impact pathway approach

\begin{tabular}{|c|c|c|c|}
\hline \multicolumn{4}{|c|}{ THE VALUATION METHOD OF ENVIRONMENTAL PRICES } \\
\hline \multirow{3}{*}{ Human health } & Health impact & Indicator & Valuation \\
\hline & Mortality & $\begin{array}{c}\text { YOLL } \\
\text { (Years of Lost Life) }\end{array}$ & \multirow{2}{*}{$\begin{array}{c}\text { VOLY [35] } \\
\text { (Value of a Life Year) }\end{array}$} \\
\hline & Morbidity & $\begin{array}{c}\text { QALY } \\
\text { (Quality-Adjusted Life Years) }\end{array}$ & \\
\hline \multirow[b]{2}{*}{ Ecosystem services } & \multicolumn{2}{|r|}{ Indicator } & Valuation \\
\hline & \multicolumn{2}{|c|}{$\begin{array}{c}\text { PDF } \\
\text { (Potentially Disappeared Fraction of Species) }\end{array}$} & $\begin{array}{c}\text { VEDP [36] } \\
\text { (Value of Ecological Damage Potential) }\end{array}$ \\
\hline \multirow{5}{*}{$\begin{array}{l}\text { Buildings/ } \\
\text { materials }\end{array}$} & \multicolumn{2}{|r|}{ Impact } & Valuation \\
\hline & \multicolumn{2}{|c|}{ Corrosion due to acidification } & NEEDS Project [37] \\
\hline & \multicolumn{2}{|c|}{ Particulate pollution } & Rabl [38] \\
\hline & \multicolumn{2}{|c|}{ Corrosion impacts on cultural heritage } & Rabl [38] VMM [39] \\
\hline & \multicolumn{2}{|c|}{ Impacts on paint and plastics } & Watkiss et al. [40] \\
\hline Resource availability & \multicolumn{3}{|c|}{ Uncertain (Further research is needed) } \\
\hline \multirow{2}{*}{ Wellbeing } & \multicolumn{2}{|r|}{ Impact } & Valuation \\
\hline & \multicolumn{2}{|c|}{ Noise nuisance } & Bristow et al. [41] \\
\hline
\end{tabular}

Years of Lost Life (YOLL) and Quality-Adjusted Life Years (QALY). Specific evaluation methods are shown in table 1.

\section{Data}

China's textile industry can be divided into three subindustries: Manufacture of Textile (MT), Manufacture of Chemical Fibers (MCF), and Manufacture of Textile, Wearing Apparel and Accessories (MTWAA). In this paper, energy consumption data and wastewater pollutants data of China's textile industry from 2001 to 2015 were collected at the national level. The wastewater pollutants in China's textile industry included $\mathrm{Hg}, \mathrm{Cd}, \mathrm{Pb}, \mathrm{As}$, cyanide, $\mathrm{COD}$ and ammonia nitrogen. Environmental prices for pollutants referred to the recommended median values in the environmental prices models. In addition, the missing environmental price of COD was obtained by converting COD into phosphorus through the characteristic factor of water degradation footprint pollutants. The specific data types and sources are shown in table 2.

industuria textillă

\begin{tabular}{|c|c|c|}
\hline \multicolumn{2}{|c|}{ SPECIFIC DATA TYPES AND SOURCES 2} \\
\hline Data type & Unit & Source \\
\hline $\begin{array}{c}\text { Energy } \\
\text { consumption }\end{array}$ & $10^{4}$ tce & $\begin{array}{c}\text { China Energy Statistical } \\
\text { Yearbook (2001-2015) [42] }\end{array}$ \\
\hline $\begin{array}{c}\text { Wastewater } \\
\text { pollutants }\end{array}$ & ton & $\begin{array}{c}\text { China Environment Yearbook } \\
\text { (2001-2007) [43] } \\
\text { Annual Statistic Report } \\
\text { on Environment in China } \\
\text { (2007-2015) [44] }\end{array}$ \\
\hline $\begin{array}{c}\text { Environmental } \\
\text { prices }\end{array}$ & $€ / k g$ & CE Delft [22] \\
\hline
\end{tabular}

\section{RESULTS AND DISCUSSION}

Based on the environmental prices methodology, the social marginal values of waste emissions from China's textile industry and the three sub-industries from 2001 to 2015 were calculated and shown in figure 3.

According to figure 3 , the social marginal value of the textile industry increased in volatility, from $€ 9.556$ 


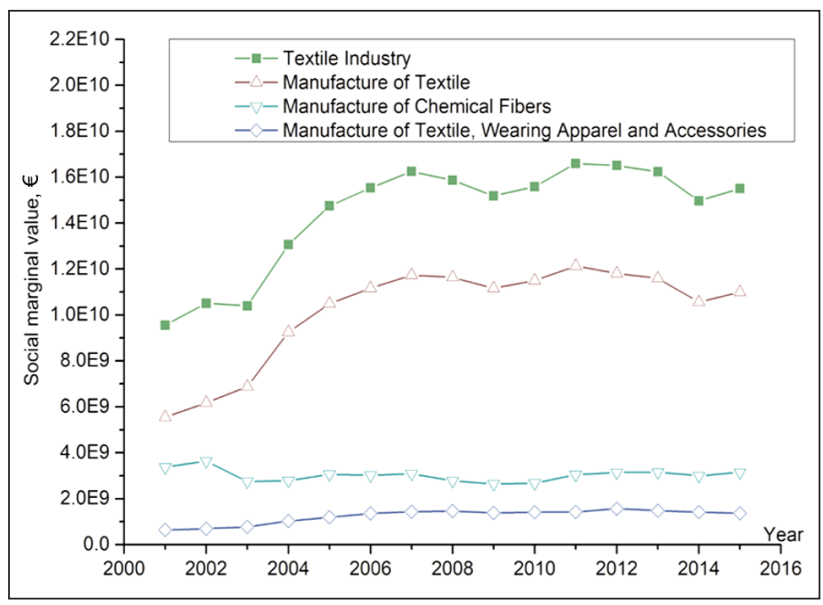

Fig. 3. The social marginal value of the textile industry and its sub-industries from 2001 to 2015

billion in 2001 to $€ 15.508$ billion in 2015 , with an increase rate of $62.30 \%$. From 2001 to 2003, the social marginal value of environment increased firstly before a little declining. While from 2004 to 2007, the value increased rapidly and reached a peak of $€ 16.252$ billion in 2007 . The reason for the sharp increase during this period was that the Chinese government issued a series of policies to accelerate the development of the textile industry. According to the data of China textile industry development report [45], the gross value of industrial output of textile enterprises above designated size increased from RMB 1610.7 billion in 2004 to RMB 3058.2 billion in 2007 , with an increase rate of $89.87 \%$.

Influenced by the global financial crisis in 2008, China's textile industry economy showed a downward trend for the first time after years of steady and rapid growth. According to the national bureau of statistics' data [45], the growth rate of the gross value of industrial output of textile enterprises above designated size dropped by $8.84 \%$ in 2008 compared with the same period in 2007 . The exports of textile and apparel also dropped by $11.13 \%$. With the overall slowdown in production and sales, the social marginal value of the textile industry experienced a synchronous decline to $€ 15.191$ billion in 2009. To cope with the sluggish economy, the government adopted a series of macro-control policies to provide a relatively loose domestic environment for China's textile industry since 2009. According to the statistics [45], the growth rate of industrial output value of the textile industry increased by $17.16 \%$ in 2010 and $26.84 \%$ in 2011 respectively. As showed in figure 3, the value increased again from 2009 to 2011, and reached the maximum value of $€ 16.599$ billion in 2011. Contrary to expectation, the social marginal value had revealed a trend of gradual decrease since 2012. Aimed at improving environmental benefit, the government issued strict restrictions on the textile industry, including energy consumption restriction, carbon dioxide emission intensity restriction, water consumption restriction and emission restriction of major pollutants. These restrictions led to the decline in social marginal value. Obviously, it can be concluded that the social marginal value of wastes in China's textile industry was not only closely related to the scale of the industry, but also influenced by the international market and government policies. Figure 3 also shows the potential contribution of social marginal value in the three sub-industries. MT was found to have the largest social marginal value followed by MCF, and MTWAA. The value of MT was much higher than that of other two industries. Another notable finding is that the fluctuation trend of MT was consistent with the general trend of the textile industry and the value of MCF and MTWAA changed slightly from 2001to 2015. It can be argued that the MT dominated the social marginal value of the textile industry, which means that the MT had a greater environmental impact.

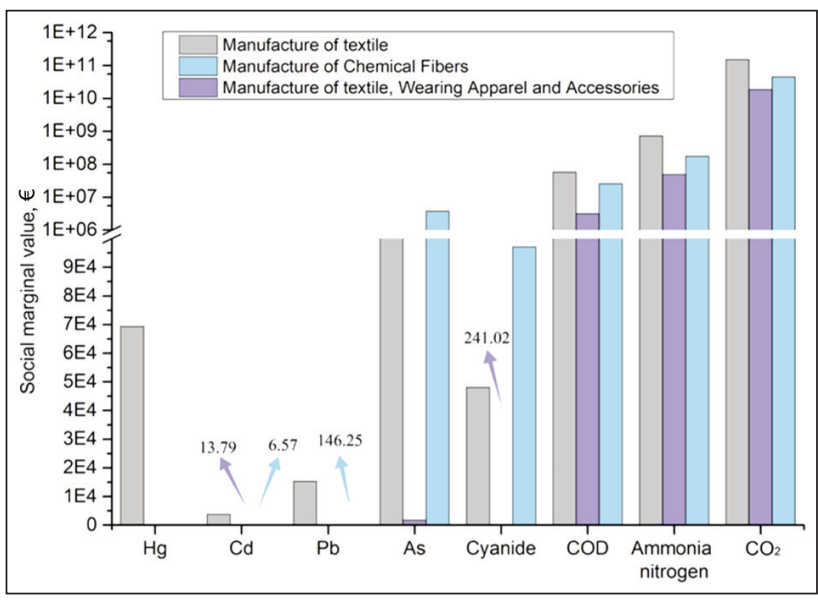

Fig. 4. The social marginal value of pollutants in three sub-industries

Figure 4 shows the social marginal value of pollutants in three sub-industries from 2001 to 2015 . The pollutant with the highest value in the three sub-industries was $\mathrm{CO}_{2}$, which contributed more than $95 \%$ of the total social marginal value. According to the results in Figure 4 , the value of ammonia nitrogen was the largest and followed by the values of COD, As, cyanide, $\mathrm{Hg}, \mathrm{Pb}$ and $\mathrm{Cd}$. Therefore, it can be concluded that ammonia nitrogen caused the greatest impact on water environment. Since there was no corresponding consumption in the production phase, the values of $\mathrm{Hg}$ and $\mathrm{Pb}$ in MCF and MTWAA were zero. The major contribution of As and cyanide came from MT and MCF. The generation of $\mathrm{Hg}$ in the textile industry was little, but the environmental price was higher than that of other pollutants due to its high toxicity and more serious damage to the environment. Therefore, its social marginal value was even higher than the sum of $\mathrm{Cd}$ and $\mathrm{Pb}$ in the three sub-industries. In general, it can be considered that ammonia nitrogen, COD were the pollutants that had the greatest impact on water environment.

\section{CONCLUSIONS}

Textile industry has a serious impact on the environment. This study applied environmental prices 
methodology to calculate the social marginal value of the environmental impacts caused by the textile industry. The results showed that the minimum social marginal value of China's textile industry was $€ 9.556$ billion and the maximum value was $€ 16.599$ billion between 2001 and 2015. Among the three sub-industries of the textile industry, MT had the highest social marginal value, while the MTWAA had the lowest. MT dominated the social marginal value of China's textile industry. The pollutant with the highest social marginal value was $\mathrm{CO}_{2}$. The value of ammonia nitrogen was the largest in wastewater and followed by the values of COD, As, cyanide, $\mathrm{Hg}, \mathrm{Pb}$ and $\mathrm{Cd}$. Environmental impact is playing an increasingly important and even decisive role in enterprises' decision-making. Environmental prices can transform various environmental impacts into a unified unit of value. It is useful in identifying pollutants that have a greater impact on the environment in an intuitive way.
Therefore, environmental prices methodology can be applied in enterprises' cost-benefit analysis and then find out the hot-spots for costs reduction.

Environmental prices methodology is also a useful tool for environmental governance. The environmental impacts of different companies can be quantified with this tool. The companies with high quantified value will be restricted and even be punished. Moreover, environmental prices methodology can also be applied in environmental tax calculation.

\section{ACKNOWLEDGEMENTS}

This research was funded by the National Key R\&D Program of China (2018YFF0215703), the Natural Science Foundation of Zhejiang Province (LY20G030001), Science and technology innovation activities of university students in Zhejiang Province (2019R406059, 2020R406074). In particular Professor Sander DE Bruyn, head of the environmental prices handbook for the support and guidance.

\section{REFERENCES}

[1] Liu, T.T., Zhang, H.D., Progress in the treatment of major pollutants in the textile industry, In: Textile Dyeing and Finishing Journal, 2016, 38, 9, 61-63

[2] Yang, A.J., Hang, C.H., Zhen, J.Y., Examination of dependence of drape coefficient on the samples size, In: Textile Dyeing and Finishing Journal, 2013, 35, 11, 46-49

[3] Chapagain, A.K., Hoekstra, A.Y., Savenije, H.H.G., The water footprint of cotton consumption: An assessment of the impact of worldwide consumption of cotton products on the water resources in the cotton producing countries, In: Ecological Economics, 2006, 60, 1, 25-47

[4] Wang, L.L., Wu, X.Y., Ding, X.M., Case study on industrial carbon footprint and industrial water footprint of cotton knits, In: Dyeing \& Finishing, 2012, 38, 7, 43-46

[5] Yan, Y., Jia, J., Wang, L.H., The industrial water footprint of several typical cotton textiles in China, In: Acta Ecologica Sinica, 2014, 34, 23, 7119-7126

[6] Yao, L., Carbon footprint evaluation on raw materials stage of textile and garment carbon emission reduction, In: Journal of Tiangong University, 2014, 33, 1, 70-76

[7] Li, X.Y., Xu, W.J., Zhu, J.Z., Calculation Method of Cotton Carded Yarn Carbon Footprint, In: Cotton Textile Technology, 2014, 42, 9, 19-23

[8] Zhao, N.H., Zhou, X., Dong, F., Carbon footprint assessment of polyester textiles, In: Dyeing \& Finishing, 2012, 38, $14,42-45$

[9] Jiang, T., Chen, Z.Y., Yao, T.T., Product carbon footprint (PCF) assessment of gambiered Canton silk, In: Dyeing \& Finishing, 2012, 38, 8, 39-41

[10] Li, Y., Wang, J.T., Wang, L.L., Demonstration of Carbon Footprint Assessment of Jean Industry, In: Advanced Textile Technology, 2017, 25, 6, 58-61

[11] Qian, J.H., Li, Y., Wang, L.L., Calculation and assessment of chemical footprint of denim fabric, In: Dyeing \& Finishing, 2018, 44, 13, 52-55

[12] Tian, Z.J., Wang, L.L., Li, Y., Calculation and assessment of chemical footprint of textiles and apparel, In: Journal of Silk, 2019, 56, 1, 33-37

[13] Manfredi, S., Allacker, K., Chomkhamsri, K., Product Environmental Footprint $\square P E F \square$ Guide, European Commission, Joint Research Centre, Ispra, Italy, 2012, 5-7

[14] He, B., Shao, Y., Wang, S., Product environmental footprints assessment for product life cycle, In: Journal of Cleaner Production, 2019, 233, 446-460

[15] Pyay, S., Thanungkano, W., Mungkalasiri, J., A life cycle assessment of intermediate rubber products in Thailand from the product environmental footprint perspective, In: Journal of Cleaner Production, 2019, 237, 117632

[16] Famiglietti, J., Guerci, M., Proserpio, C., Development and testing of the Product Environmental Footprint Milk Tool: A comprehensive LCA tool for dairy products, In: Science of The Total Environment, 2019, 648, 1614-1626

[17] Wade, A., Stolz, P., Frischknecht R., The Product Environmental Footprint (PEF) of photovoltaic modules - Lessons learned from the environmental footprint pilot phase on the way to a single market for green products in the European Union, In: Progress in Photovoltaics: Research and Applications, 2018, 268, 553-564

[18] Soode-Schimonsky, E., Richter, K., Weber-Blaschke, G., Product environmental footprint of strawberries: Case studies in Estonia and Germany, In: Journal of environmental management, 2017, 203, 564-577

[19] Russo, C., Cappelletti, G.M., Nicoletti, G.M, Product environmental footprint in the olive oil sector: state of the art, In: Environmental Engineering \& Management Journal, 2016, 159, 2019-2027

[20] Goedkoop, M., Heijungs, R., Huijbregts, M., "ReCiPe 2008." A life cycle impact assessment method which comprises harmonised category indicators at the midpoint and the endpoint level 1, Ministry of Housing, Spatial Planning and Environment (VROM), Netherlands, 2009, 1-126 
[21] ETSU, Harwell, Didcot, ExternE: Externalities of energy Vol. 2. Methodology, European Commission, Brussels, 1995, 7-26

[22] De, B.S., Ahdour, S., Bijleveld, M., Environmental Prices Handbook 2017: Methods and numbers for valuation of environmental impacts, CE Delft, Netherlands, 2018, 4-125

[23] De, B.S., Ahdour, S., Bijleveld, M., Environmental Prices Handbook EU28 version: Methods and numbers for valuation of environmental impacts, CE Delft, Netherlands, 2018, 4-124

[24] True Price, IDH, The true price of cotton from India, True Price, Amsterdam, Netherlands, 2016, 14-24

[25] True Price, The true price of jeans, True Price, Amsterdam, Netherlands, 2019, 10-15

[26] IDH, True Price, The true price of cocoa from Ivory Coast, True Price, Amsterdam, Netherlands, 2016, 14-18

[27] True Price, IDH, The true price of tea from Kenya, True Price, Amsterdam, Netherlands, 2016, 14-18

[28] True Price, Trucost, The external costs of banana production: A global study, True Price, Amsterdam, Netherlands, 2017, 20-35

[29] Se, P., PUMA's Environmental Profit and Loss Account for the Year Ended 31 December 2010, Truecost, Herzogenaurach, Germany, 2011, 6-8

[30] NIRAS, Trucost, Novo Nordisk's environmental profit and loss account, The Danish Environmental Protection Agency, Strandgade, Denmark, 2014, 20-27

[31] Trucost, Plastics and sustainability: A valuation of environmental benefits, costs and opportunities for continuous improvement, Trucost, London, UK, 2016, 22-45

[32] Trucost, Growing business value in an environmentally challenged economy, Trucost, London, UK, 2016, 1-13

[33] PwC, Valuing corporate environmental impacts, PWC, UK, 2015, 27-413

[34] True Price, A roadmap for true pricing, True Price, Amsterdam, Netherland, 2019, 2-16

[35] Desaigues, B., Ami, D., Hutchison, M., Rabl, A., Chilton, S., Final report on the monetary valuation of mortality and morbidity risks from air pollution. Deliverable D6, 7, NEEDS project, Stuttgart, 2007, 20-22

[36] Kuik, O., Brander, L., Nikitina, N., Navrud, S., Magnussen, K., Fall, E.H., Energy-related external costs due to land use changes, acidification and eutrophication, visual intrusion and climate change, European Commission, 2007, 8-23

[37] Preiss, P., Friedrich, R., Klotz, V., Report on the procedure and data to generate averaged/aggregated data. NEEDS project, Stuttgart, 2008, 10-16

[38] Rabl, A., Air pollution and buildings: an estimation of damage costs in France, In: Environmental Impact Assessment Review, 1999, 19, 4, 361-385

[39] VMM, Myriam B., MIRA, Milieurapport Vlaanderen MIRA: Themabeschrijving Zwevend stof, Vlaamse Milieumaatschappij, Mechelen, 2013, 7-25

[40] Watkiss, P., Holland, M., Hurley, F., Pye, S., Damage Costs for Air Pollution, Defra, London, 2006, 1-21

[41] Bristow, A.L., Wardman, M., Chintakayala, V.P.K., International meta-analysis of stated preference studies of transportation noise nuisance, In: Transportation, 2015, 42, 1, 71-100

[42] Department of Energy Statistics, National Bureau of Statistics, China Energy Statistical Yearbook, China Statistics Press, China, 2001- 2015

[43] Editorial board of China Environment Yearbook, China Environment Yearbook, China Environmental Yearbook Press, China, 2001-2007

[44] Ministry of Environmental Protection of the People's Republic of China, Annual Statistic Report on Environment in China, China Environmental Press, China, 2007- 2015

[45] China National Textile and Apparel Council, China Textile Industry Development Report, China Textile \& Apparel Press, China, 2001-2015

\section{Authors:}

\section{JIANG CHU ${ }^{1,2}$, LIRONG SUN ${ }^{3}$, FANGLI CHEN ${ }^{1,2}$, XIANG JI $^{1,2}$, ZEJUN TIAN ${ }^{1,2}$, LAILI WANG $2,4,5$}

${ }^{1}$ School of Fashion Design \& Engineering, Zhejiang Sci-Tech University, Hangzhou, Zhejiang 310018, China e-mail: chujiangZSTU@163.com (C.J.), cathychen2016@163.com (C.F.), jixiang549961547@163.com (J.X.),15003416393@sina.cn (T.Z.)

${ }^{2}$ Zhejiang Sci-Tech University, Engineering Research Center of Clothing of Zhejiang Province, 310018, Hangzhou, China

${ }^{3}$ Office for Social Responsibility of China National Textile and Apparel, Beijing, 100027, China e-mail: sunlirong@ctic.org.cn (S.L.)

${ }^{4}$ Silk and Fashion Culture Research Center of Zhejiang Province, Zhejiang Sci-Tech University, 310018, Hangzhou, Zhejiang, China

${ }^{5}$ Zhejiang Academy of Ecological Civilization, Hangzhou 310018, China

\section{Corresponding author:}

LAILI WANG

e-mail: wangll@zstu.edu.cn 